\title{
ХРЕБЕТ ДЖУГДЖУР КАК ГЕОГРАФИЧЕСКАЯ ПРЕГРАДА ДЛЯ РАСПРОСТРАНЕНИЯ ЖИВОТНЫХ (на примере землероек-бурозубок)
}

\author{
Н. Е. Докучаев \\ ФГБУН Институт биологических проблем Севера ДВО РАН, г. Магадан \\ E-mail: dokuchaev@ibpn.ru
}

\begin{abstract}
Показано, что видовой состав и структура сообществ землероек-бурозубок Западного Приохотья и правобережья р. Алдан, разделенных хр. Джугджур и Юдомо-Майским нагорьем, существенно различаются. Объясняется это наличием двух независимых путей расселения бурозубок на север (по территории Якутии и вдоль Охотского побережья), а также их ограниченными возможностями к преодолению Охотско-Алданского водораздела.
\end{abstract}

Ключевые слова: бурозубки, Sorex, хр. Джугджур, Приохотье, Якутия, географическая преграда.

DOI: 10.34078/1814-0998-2019-4-66-72

В зоогеографии специфика региональных исследований состоит в возможности связать фаунистический состав, структуру сообществ и распределение животного населения с географическими особенностями и историей конкретной территории. Хребет Джугджур, вытянутый вдоль морского побережья, отделяет Западное Приохотье от материковой части Восточной Сибири. Вместе с Верхоянским и Становым хребтами он образует протяженную горную цепь, ограничивающую распространение животных. Территория эта остается слабо изученной в териологическом отношении. Лишь в окрестностях трех населенных пунктов (Чумикане, Аяне и Охотске) западного побережья Охотского моря проводились сборы мелких млекопитающих и имеются данные о видовом составе бурозубок. Эта часть Охотского побережья рассматривается и как своего рода экологический «коридор», по которому в прошлом в благоприятные периоды многие виды растений и животных распространялись далеко на север (Докучаев, 2012). Последнее такое продвижение было связано с голоценовым климатическим оптимумом. Этим путем, например, дальневосточная бурозубка (Sorex gracillimus Thomas, 1907), обыкновенная кутора (Neomys fodiens Pennant, 1771) и восточноазиатская мышь (Apodemus peninsulae Thomas, 1907) распространились севернее $60^{\circ}$ с. ш. (Докучаев, 2012), а дальневосточная лягушка (Rana dybowskii Gunther, 1876) достигла Охотска. Напротив, в периоды

(C) Докучаев Н. Е., 2019 похолоданий северные формы получали возможность расширять свои южные границы обитания. Так, на о. Сахалин среди представителей четвертичной фауны числятся такие «северные экзоты», как овцебык (Ovibos moschatus Zimmerman, 1780) и копытный лемминг (Dicrostonyx torquatus Pallas, 1778) (Алексеева, Горбунов, 2007).

Большую часть центральной Якутии занимает Приленское плато, восточные пределы которого граничат с горными хребтами (Верхоянским и Джугджуром), а также Юдомо-Майским и Алданским нагорьями. Южнее Алданского нагорья почти в широтном направлении протянулся Становой хребет, образующий водораздел между бассейном Амура и реками, текущими в Северный Ледовитый океан. Территория центральной Якутии, в свою очередь, характеризуется набором млекопитающих, ареалы которых на востоке «упираются» в Верхоянский хребет. Это водяная полевка (Arvicola amphibius L., 1758), темная полевка (Microtus agrestis L., 1761), якутская, или короткохвостая, узкочерепная полевка (Lasiopodomys gregalis brevicauda, Kastschenko, 1901) и сибирская косуля (Capreolus pygargus Pallas, 1771) (Млекопитающие ..., 1971; Павлинов и др., 2002). Известно, что высокие хребты создают непреодолимую преграду для распространения, в первую очередь, равнинных видов животных. То, что вдоль юго-западного склона Верхоянского хребта наблюдается сгущение границ ареалов (синператы) ряда видов млекопитающих, ранее отмечалось в работах В. Г. Кривошеева (1973, 1988). Было установлено, что структура сооб- 
ществ бурозубок Западного Приохотья и правобережья Алдана также существенно различается (Докучаев, 2013).

Цель проведенного исследования состояла в детализации особенностей современного распространения видов бурозубок на разных сторонах Охотско-Алданского водораздела, а также оценке хр. Джугджур как географической преграды для этой группы насекомоядных. бурозубки представлены семью видами: средней (S. caecutiens Laxmann, 1788), крупнозубой $(S$. daphaenodon Thomas, 1907), равнозубой (S. isodon Turov, 1924), когтистой (S. unguiculatus Dobson, 1890), бурой (S. roboratus Hollister, 1913), дальневосточной (S. gracillimus) и крошечной $(S$. minutissimus Zimmermann, 1780).

Сведения о видовом составе и структуре сообществ землероек-бурозубок правобережья сред-

\section{МАТЕРИАЛ И МЕТОДЫ}

Данные о бурозубках Охотского побережья и юго-западной Якутии основаны на личных сборах автора и просмотре музейных коллекций. В районе Охотска материал собирался с 19 июня по 1 июля 1971 г. на левом берегу р. Кухтуй, в 4 км выше пос. Резиденция (рис. 1). В 2003 г. отлов бурозубок здесь проводился с 5 по 19 сентября также вблизи пос. Резиденция и у Охотска. Всего за два года в данном районе отловлено 76 бурозубок шести видов (см. таблицу).

В центральной Якутии материал собирался с 30 июля по 22 августа 2006 г. (в составе российскоамериканской группы) в ряде пунктов по р. Амга, в окрестностях г. Якутск и на р. Кенкеме в 40 км к западу от Якутска. Всего в 2006 г. отловлено 150 бурозубок пяти видов (см. таблицу). В музее Института биологических проблем криолитозоны СО РАН (г. Якутск) были просмотрены сборы бурозубок из низовьев р. Мая (устье р. У-Юрях; 59 $58.637^{\prime}$ с. ш., $134^{\circ} 51.010^{\prime}$ в. д.).

С 1989 по 1992 г. там было отловлено 2410 бурозубок пяти видов (см. таблицу). Были просмотрены также бурозубки с территории Якутии и Охотского побережья в музее Зоологического института (ЗИН) РАН (г. Санкт-Петербург), Зоологическом музее МГУ (г. Москва), музее Института систематики и экологии животных СО РАН (г. Новосибирск). Также учитывались данные, представленные в литературных источниках (Алина, Реймерс, 1975; Егоров, Ревин, 1992; Ревин, 2003; Тиунов, 2003а, б; Мордосов, 2010).

\section{РЕЗУЛЬТАТЫ И ОБСУЖДЕНИЕ}

В настоящее время на Охотском побережье от устья р. Уда до Охотска

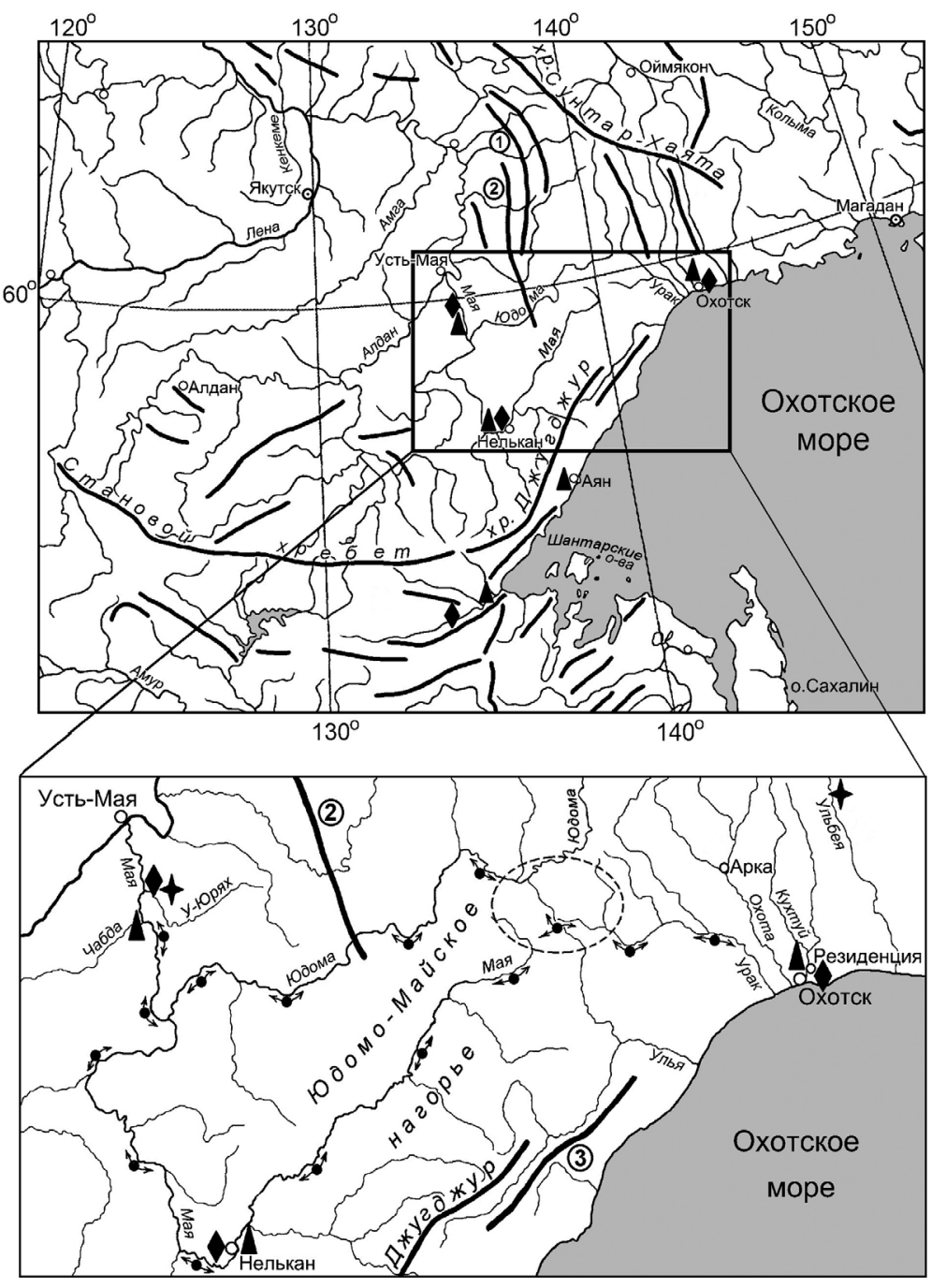

Puc. 1. Карта юго-восточной Якутии и Западного Приохотья. Условные обозначения: $\$ - горные хребты (цифрами обозначены: 1 - хр. Сетте-Дабан, 2 - хр. Улахан-Бом, 3 - хр. Ульинский); мая pp. Мая, Юдома, Урак (местоположение водораздела обозначено пунктирным овалом); места отлова трех видов бурозубок: $\boldsymbol{\Lambda}-S$. isodon, $\boldsymbol{\uparrow}$-S. roboratus, $\boldsymbol{\uparrow}-S$. tundrensis

Fig. 1. Map of Southeastern Yakutia and Western Priokhotye. Legend: $\checkmark$ - mountain ranges (1 - Sette-Daban Ridge, 2 - UlakhanBom Rridge, 3 - Ulyinsky Ridge); shrews counter passage along the valleys of the Maya, Yudoma, Urak rivers (the watershed location is indicated by the dotted oval); places of catching three shrew species: $\boldsymbol{\Delta}-S$. isodon, $\boldsymbol{\nabla}$. roboratus, $\boldsymbol{\downarrow}-S$. tundrensis 
Видовой состав и количество отловленных бурозубок в Западном Приохотье, центральной и юговосточной Якутии

Species composition and number of shrews caught in Western Priokhotye, Central and Southeastern Yakutia

\begin{tabular}{|c|c|c|c|c|c|c|c|c|}
\hline \multirow{3}{*}{ Виды бурозубок } & \multicolumn{4}{|c|}{ Западное Приохотье } & \multirow{2}{*}{\multicolumn{2}{|c|}{$\begin{array}{c}\text { Центральная Якутия } \\
\text { Якутск, Амга, Кенкеме } \\
\text { (2006 г.) }\end{array}$}} & \multirow{2}{*}{\multicolumn{2}{|c|}{$\begin{array}{c}\begin{array}{c}\text { Юго-восточная } \\
\text { Якутия }\end{array} \\
\text { У-Юрях } \\
(1989-1992 \text { гг.) }\end{array}$}} \\
\hline & \multicolumn{2}{|c|}{$\begin{array}{c}\text { Охотск } \\
\text { (1971 и } 2003 \text { г.) }\end{array}$} & \multicolumn{2}{|c|}{$\begin{array}{c}\text { Аян } \\
\text { (1965 г.; Алина, } \\
\text { Реймерс, 1975) }\end{array}$} & & & & \\
\hline & ЭКз. & $\%$ & эКз. & $\%$ & ЭКз. & $\%$ & ЭКз. & $\%$ \\
\hline S. caecutiens & 26 & 34.2 & 160 & 55.9 & 51 & 34.0 & 1385 & 57.5 \\
\hline S. daphaenodon & 1 & 1.3 & - & - & 14 & 9.3 & 335 & 13.9 \\
\hline S. gracillimus & 9 & 11.8 & 4 & 1.8 & - & - & - & - \\
\hline S. isodon & 35 & 46.1 & 120 & 42.0 & - & - & - & - \\
\hline S. minutissimus & 2 & 2.6 & 1 & 0.3 & 5 & 3.3 & 60 & 2.5 \\
\hline S. roboratus & 3 & 4.0 & - & - & 34 & 22.7 & 440 & 18.2 \\
\hline S. tundrensis & - & - & - & - & 46 & 30.7 & 190 & 7.9 \\
\hline Всего: & 76 & 100 & 285 & 100 & 150 & 100 & 2410 & 100 \\
\hline
\end{tabular}

него течения р. Алдан ограничены лишь данными по низовьям р. Мая. Состав бурозубок в устье р. У-Юрях (правого притока р. Мая) включал пять видов $(S$. caecutiens, $S$. daphaenodon, $S$. minutissimus, $S$. roboratus и $S$. tundrensis Merriam, 1900) (см. таблицу). Указания, что в устье p. У-Юрях была отловлена малая бурозубка $(S$. minutus L., 1766) (Егоров, Ревин, 1992; Ревин, 2003), не были подтверждены конкретным материалом и признаны ошибочными (личн. общение с Ю. В. Ревиным). Заслуживает внимания то, что среди 2410 бурозубок с У-Юряха не было ни одного экземпляра $S$. isodon. При этом всего в 23 км выше по течению Маи в устье р. Чабда в 2008 г. были отловлены 4 экз. этого вида (коллекция Зоологического музея МГУ).

Рассмотрим особенности в распространении и численность (долевое участие) разных видов бурозубок в Западном Приохотье, юго-восточной Якутии и на сопредельных территориях:

Средняя бурозубка - самый многочисленный вид, отмеченный во всех исследованных пунктах. Следует указать, что на западной и восточной сторонах Охотско-Алданского водораздела эта бурозубка представлена разными подвидами. Бассейн Алдана населяет S. c. caecutiens Laxmann, 1788, а Приохотье - S. c. macropygmeus Miller, 1901 (Юдин, 1989).

Равнозубая бурозубка населяет все Охотское побережье, проникая в верховья Колымы, на Камчатку и Чукотку (в бассейн Анадыря). В поймах рек, в особенности в тополево-чозениевых насаждениях, доминирует по численности среди бурозубок. В бассейне р. Мая ее отлавливали у пос. Нелькан (Тиунов, 2003б; коллекция ЗИН) и в устье р. Чабда (коллекция Зоологического музея МГУ), но уже ниже по течению (в устье р. У-Юрях) отсутствовала в большой выборке бурозубок (см. таблицу). Южная Якутия входит в зону сплошного распространения равнозубой бурозубки (Ревин, 1989), но на западе центральной Якутии - это уже редкий вид (Попов, 1975, 1977; Вольперт, Шадрина, 2002). В наших сборах из окрестностей Якутска и по p. Амга равнозубая бурозубка отсутствовала, не приводится она для Лено-Алданского междуречья и в других источниках (Попов, 1977; Мордосов, 2010).

Крупнозубую бурозубку на Охотском побережье и в бассейне р. Мая добывали во всех пунктах, за исключением пос. Аян (Алина, Реймерс, 1975; Тиунов, 2003а, б). В низовьях р. Мая в устье р. У-Юрях доля этого вида в сообществе бурозубок составляла $13.9 \%$ (см. таблицу).

Бурая бурозубка в низовьях р. Мая уступала в численности только средней бурозубке (см. таблицу). В 1971 г. 3 экз. S. roboratus были добыты нами в низовьях р. Кухтуй, в 4 км выше пос. Резиденция. В 1973 г. у пос. Нелькан 3 экз. этого вида отловил В. А. Костенко (коллекция ЗИН), а в 1999 г. - 1 экз. М. П. Тиунов (2003б). В окрестностях Аяна бурая бурозубка в уловах отсутствовала (Алина, Реймерс, 1975; Тиунов, 2003б). В бассейне р. Уда $S$. roboratus была отловлена в 140 км от побережья (Тиунов, 2003а, б), куда могла попасть с Верхнезейской равнины. Доходит ли эта бурозубка по долине Уды до морского побережья, остается не известным. В пределы северо-восточной Азии этот вид проник с запада северным путем в обход Верхоянского хребта (Докучаев, 1999). В настоящее время населяет бассейны Индигирки и Колымы, но на Охотское побережье с них не выходит (Андреев и др., 2006). Единственным таким местом оказываются окрестности Охотска, куда попасть эта бурозубка могла только с Алдана. 
Тундровая бурозубка отсутствует на большей части Охотского побережья. Показано, что заселение северо-востока Азии тундровой бурозубкой, как и предыдущим видом, проходило исключительно северным путем в обход Верхоянского хребта (Докучаев, 1999; Bannikova et al., 2010). В сообществе бурозубок в низовьях р. Мая ее доля составляла $7.9 \%$, уступая средней, бурой и крупнозубой бурозубкам. Ни в среднем течении p. Мая у пос. Нелькан, ни у пос. Охотск эта бурозубка не была отмечена. На Охотском побережье она появляется уже гораздо севернее - в устье р. Булун и у пос. Эвенск (Кищинский, 1972; Докучаев, Поспехов, 2008). При этом следует отметить, что в верховьях рек охотоморского бассейна (Ульбеи и Ямы) этот вид добывался (см. рис. 1; Андреев и др., 2006).

Дальневосточная бурозубка распространена исключительно по Охотскому побережью, заходя северо-восточной периферией своего ареала в юго-западные пределы Магаданской области (Докучаев, 1990, 2012; Докучаев и др., 2011).

Крошечная бурозубка отмечена во всех пунктах отлова, но везде с низкой численностью.

Когтистую бурозубку отлавливали только в окрестностях пос. Чумикан (Тиунов, 2003б) и севернее бассейна р. Уда ее не отмечали.

Видовой состав и структура сообществ бурозубок окрестностей Аяна и Охотска достаточно близки (см. таблицу). У Аяна в уловах доминировали средняя и равнозубая бурозубки, долевое участие которых составляло соответственно 55.9 и $42 \%$, а на дальневосточную и крошечную бурозубок вместе приходилось только $2.1 \%$. В окрестностях Охотска средняя и равнозубая бурозубки также преобладали в уловах, причем первое место здесь перешло к равнозубой бурозубке. Последнее связано исключительно с тем, что у Охотска преимущественно облавливались пойменные биотопы, в которых эта бурозубка доминирует в численности.

Совсем другая картина обнаруживается при сравнении видового состава и структуры сообществ бурозубок на разных сторонах Охотско-Алданского водораздела (рис. 2). Эти выборки сближает лишь доминирование в обоих случаях средней бурозубки. В остальном они существенно различаются. Так, в Приохотье доля S. isodon в сообществе бурозубок составляла $42.9 \%$. Преодолев водораздел, эта бурозубка по долине Маи распространилась до устья Чабды. Однако уже в устье У-Юряха она не была оби Охотска) Okhotsk) наружена. Бурая, крупнозубая и тундровая бурозубки - обычные виды в устье У-Юряха (см. рис. 2), но на охотской стороне первые два вида оказываются в категории редких, а тундровая бурозубка вовсе отсутствует.

Известно, что с продвижением на север большинство видов бурозубок начинают тяготеть к нижним уровням речных долин. Из рассмотренных нами видов лишь средняя бурозубка осваивает весь спектр биотопов от пойм до горных тундр (Докучаев, 1990). В свете представленных данных становится очевидным, что хр. Джугджур вкупе с Верхоянским и Становым хребтами существенно ограничивает обмен бурозубок между Приохотьем и бассейном Алдана. Задействованы в этом и отроги Верхоянского хребта - хребты Сетте-Дабан и Улахан-Бом (см. рис. 1). Так, дальневосточная и тундровая бурозубки не смогли осилить Охотско-Алданский водораздел. Равнозубая и бурая бурозубки преодолели эту преграду, однако в конечных пунктах (для $S$. isodon это устье р. Чабда, а для $S$. roboratus - окрестности Охотска) они из положения доминанта и субдоминанта перешли в категорию редких видов. Поскольку $S$. isodon и $S$. roboratus в основном населяют пойменные биотопы, их продвижение могло осуществляться исключительно по долинам рр. Мая и Юдома, пронизывающих Юдомо-Майское нагорье (см. рис. 1). Из грызунов этот же путь с Алдана на Охотское побережье совершила мышь-малютка - Micromys minutus (Pallas, 1771) (Dokuchaev, 2004). Казалось бы, что для красной (Clethrionomys rutilus Pallas, 1779) и красно-серой (Craseomys rufocanus Sundevall, 1846) полевок, осваивающих широкий диапазон высот, хр. Джугджур не может составить серьезной преграды. Тем не менее, как и у средней бурозубки, Приохотье и бассейн Алдана населяют разные подвидовые формы этих полевок (Громов, Ербаева, 1995), что свидетельствует об отсутствии или минимальном обмене между их
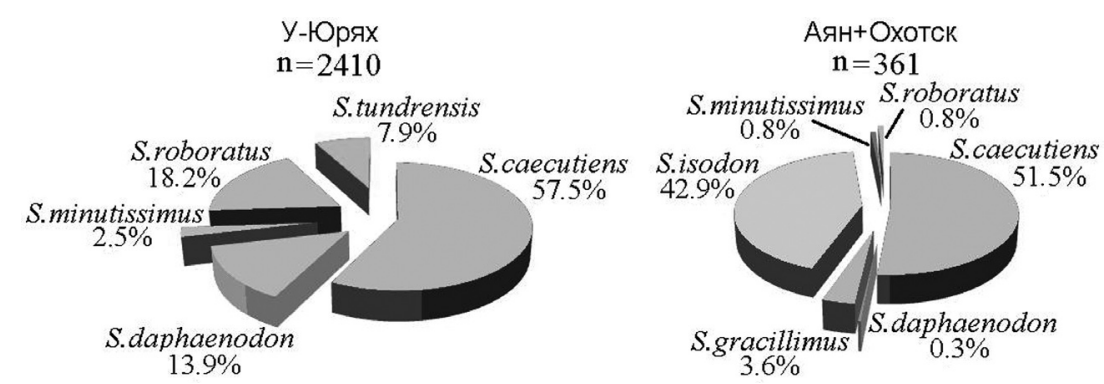

Puc. 2. Соотношение видов в сообществах бурозубок юго-восточной Якутии (У-Юрях) и Западного Приохотья (объединенная выборка из Аяна

Fig. 2. Species ratio in shrew communities of the Southeastern Yakutia (U-Yuryakh) and Western Priokhotye (combined sampling from Ayan and 
популяциями. Все эти данные указывают на то, что в Восточной Сибири в постледниковье существовали два независимых пути расселения млекопитающих на север - по территории Якутии и вдоль Охотского побережья.

Для Якутии и Северо-Восточной Азии разработано несколько вариантов зоогеографического районирования по териологическим данным (Егоров, Наумов, 1965; Чернявский, 1978, 1984; Кривошеев, 1988; Мордосов, 1997). Все авторы подчеркивали большое значение Верхоянского хребта как естественного зоогеографического рубежа. Хребет Джугджур при этом оказался вне рассматриваемых территорий, поскольку, с одной стороны, находится за пределами административных границ Якутии, с другой - зоогеографические выделы Северо-Восточной Азии на юге ограничивались Охотском.

Несомненно, горная система, образованная Верхоянским, Джугджуром и Становым хребтами и протянувшаяся от побережья Северного Ледовитого океана до Амура, нуждается в более глубоком исследовании в части воздействия на распространение разных групп живых организмов. Представленные в статье данные показывают, что хр. Джугджур при этом заслуживает не менее пристального внимания, чем «признанные» в зоогеографии преграды в виде Верхоянского и Станового хребтов.

Исследование частично поддержано грантом РФФИ № 18-04-00579а. Автор также благодарен администрации ИБПК СО РАН за предоставленную возможность обработки коллекции бурозубок с У-Юряха.

\section{ЛИТЕРАТУРА}

Алексеева Э. В., Горбунов С. В. К истории изучения четвертичной фауны острова Сахалин // Териофауна России и сопредельных территорий (VIII съезд Териол. о-ва): Материалы междунар. совещ. (Москва, 31 янв. - 2 февр. 2007 г.). М. : Тов-во науч. изданий КМК, 2007. C. 12.

Алина А. В., Реймерс Н. Ф. Наземные млекопитающие (Mammalia) Аянского побережья Охотского моря // Систематика, фауна, зоогеография млекопитающих и их паразитов. Новосибирск : Наука, 1975. С. 127-140 (Фауна Сибири. Тр. Биол. ин-та СО АН СССР ; вып. 23).

Андреев А. В., Докучаев Н. Е., Кречмар А. В., Чернявский $Ф$. Б. Наземные позвоночные Северо-Востока России : аннотированный каталог : изд. 2-е, перераб. и доп. Магадан : СВНЦ ДВО РАН, 2006. 315 c.

Вольперт Я. Л., Шадрина Е. Г. Мелкие млекопитающие северо-востока Сибири. Новосибирск : Наука, 2002. 246 с.

Громов И. М., Ербаева М. А. Млекопитающие фауны России и сопредельных территорий. Зайцеобразные и грызуны. СПб. : ЗИН РАН, 1995. 522 с. (Определители по фауне России, издаваемые Зоологическим институтом РАН ; вып. 167).
Докучаев Н. Е. Биогеография и таксономическое разнообразие землероек Северо-Восточной Азии // ДАН. 1999. Т. 364, № 3. С. 420-422.

Докучаев H. E., Поспехов В. В. Землеройки материкового побережья залива Шелихова (Охотское море) // Сохранение биоразнообразия Камчатки и прилегающих морей : Материалы IX междунар. науч. конф. (П.-Камчатский, 25-26 нояб. 2008 г.). П.-Камчатский : Камчатпресс, 2008. С. 308-310.

Докучаев Н. Е., Дубинин Е. А., Лазуткин А. Н. и $\partial p$. Млекопитающие // Растительный и животный мир заповедника «Магаданский». Магадан : СВНЦ ДВО PAH, 2011. C. 156-177, 283-285.

Докучаев Н. Е. Особенности распространения землероек (Soricomorpha) и грызунов (Rodentia) на материковом побережье Охотского моря // Вестник СВНЦ ДВО РАН. 2012. № 3. С. 118-123.

Докучаев H. Е. Структура сообществ бурозубок (Sorex, Mammalia) юго-восточной Якутии // Чтения памяти акад. К. В. Симакова : Материалы докладов Всерос. науч. конф. (Магадан, 26-28 нояб. 2013 г.). Магадан : СВНЦ ДВО РАН, 2013. С. 130-131.

Докучаев H. E. Экология бурозубок СевероВосточной Азии. М. : Наука, 1990. 160 с.

Егоров О. В., Наумов С. П. Животный мир // Якутия. М. : Наука, 1965. С. 293-328.

Егоров Н. Г., Ревин Ю. В. Состав фауны и биотопическое распределение землероек р. Sorex в юговосточной Якутии / I Всесоюз. совещ. по биологии насекомоядных млекопитающих (4-7 февр. 1992 г., Новосибирск). М., 1992. С. 52-54.

Кищинский А. А. Новые данные о распространении и биологии млекопитающих Колымского нагорья // Териология. Новосибирск : Наука, 1972. Т. 1. C. 192-205.

Кривошеев В. Г. Проблемы териогеографии Северо-Восточной Азии // Общая и региональная териогеография. М. : Наука, 1988. С. 33-74.

Кривочеев В. Г. Современные ландшафты и распространение млекопитающих в Северо-Восточной Азии // Биологические проблемы Севера. Магадан : ИБПС ДВНЦ АН СССР, 1973. Вып. 2. С. 24-35.

Млекопитаюшие Якутии. М. : Наука, 1971. 660 с.

Мордосов И. И. Млекопитающие Западной Якутии (фауна, экология, проблемы охраны и рационального использования): дис. в виде науч. доклада на соиск. уч. степени д-ра биол. наук. Якутск, 1997. 63 с.

Мордосов И. И. Фауна млекопитающих ЛеноАмгинского междуречья // Вестник Якут. гос. ун-та им. М. К. Аммосова. 2010. Т. 7, № 2. С. 9-19.

Павлинов И. Я., Крускоп С. В., Варшавский А. А., Борисенко А. В. Наземные звери России : справочникопределитель. М. : Тов-во науч. изданий КМК, 2002. $298 \mathrm{c}$.

Попов М. В. Определитель млекопитающих Якутии. Новосибирск : Наука, 1977. 424 с.

Попов М. В. Фауна мелких млекопитающих восточной части Лено-Вилюйского междуречья (Долина реки Кенкеме) // Экология мелких млекопитающих Якутии. Якутск : Кн. изд-во, 1975. С. 57-117.

Ревин Ю. В. Малая бурозубка // Красная книга Республики Саха (Якутия). Якутск : ГУП НИПК «Сахаполиграфиздат», 2003. Т. 2. С. 146-147. 
Ревин Ю. В. Млекопитающие Южной Якутии. Новосибирск : Наука, 1989. 321 с.

Тиунов М. П. Новые данные по распространению мелких млекопитающих в Приохотье и сопредельных областях // Зоол. журн. 2003а. Т. 82, № 1. С. 123-125.

Тиунов М. П. Фауна и особенности распространения насекомоядных и грызунов северо-западного Приохотья // Там же. 2003б. Т. 82, № 6. С. 708-713.

Чернявский $\Phi$. Б. Млекопитающие крайнего северо-востока Сибири. М. : Наука, 1984. 389 с.

Чернявский Ф. Б. Проблема районирования в зоогеографии суши и подразделение Северо-Восточной Сибири по териологическим данным // Фауна и зоо- география млекопитающих Северо-Востока Сибири. Владивосток : ДВНЦ АН СССР, 1978. С. 325.

Юдин Б. С. Насекомоядные млекопитающие Сибири. Новосибирск : Наука, 1989. 360 с.

Bannikova A. A., Dokuchaev N. E., Yudina E. V., et al. Holarctic phylogeography of the tundra shrew (Sorex tundrensis) based on mitochondrial genes // Biological Journal of the Linnean Society. 2010. Vol. 101, No. 3. P. 721-746.

Dokuchaev N. E. First registration of the harvest mouse (Micromys minutus Pallas) in Magadan Province, Russia // Russian Journal of Theriology. 2004. Vol. 3, No. 2. P. 59-61.

Поступила в редакичю 06.03.2019 2.

Поступила после доработки 05.04.2019 г.

\title{
DZHUGDZHUR RIDGE AS A GEOGRAPHICAL BARRIER FOR ANIMAL DISTRIBUTION (Exemplified by the Sorex Shrews)
}

\author{
N. E. Dokuchaev
}

\section{Institute of Biological Problems of the North, FEB RAS, Magadan}

It is shown that the species composition of shrews and structure of their communities in Western Priokhotye and on right bank of the Aldan river, separated by the Dzhugdzhur ridge and the YudomoMaya upland, differ significantly. This is explained by the existence of two independent ways of the shrew northward Colonization (around the territory of Yakutia and along the coast of the Sea of Okhotsk), as well as by their limited capability to overcome the Okhotsk-Aldan watershed.

\section{Keywords: shrews, Sorex, Dzhugdzhur Ridge, Priokhotye, Yakutia, geographical barrier.}

\section{REFERENCES}

Alekseeva, E. V.; Gorbunov, S. V., 2007, On the History of Studying the Quaternary Fauna of Sakhalin Island, Teriofauna of Russia and Adjacent Territories, VIII Congress of Russian Theriological Society, Proceedings of the International Meeting (Moscow, January 31 - February 2, 2007), Moscow, KMK Scientific Press, 12 [In Russian]. Alina, A. V.;Reymers, N. F., 1975, Terrestrial Mammals (Mammalia) of the Ayan Coast of Sea of Okhotsk, Systematics, Fauna, Zoogeography of Mammals, and Their Parasites, Novosibirsk, Nauka, 127-140 (Fauna of Siberia, Proceedings of Biological Institute of SD AS USSR, 23) [In Russian].

Andreev, A. V.; Dokuchaev, N. E.; Krechmar, A. V.; Chernyavsky, F. B., 2006, Terrestrial Vertebrates of Russia's North-East: Annotated Catalog of Species Distribution and Biology, Magadan, IBPN FEB RAS [In Russian].

Bannikova, A. A.; Dokuchaev, N. E.; Yudina, E. V.; Bobretzov, A. V.; Sheftel, B. I.; Lebedev, V. S., 2010, Holarctic Phylogeography of the Tundra Shrew (Sorex tundrensis) Based on Mitochondrial Genes, Biological Journal of the Linnean Society, 101, 3, 721-746.

Chernyavsky, F. B., 1978, Problem of Zoning in Land Zoogeography and the Division of Northeastern Siberia by the Teriological Data, Fauna and Zoogeography of Mammals in Siberia's North-East, Vladivostok, DVNC AN USSR, 3-25 [In Russian].
Chernyavsky, F. B., 1984, Mammals of the Far NorthEast of Siberia, Moscow, Nauka [In Russian].

Dokuchaev, N. E., 1990, Ecology of Shrews in Northeast Asia, Moscow, Nauka [In Russian].

Dokuchaev, N. E., 1999, Biogeography and Taxonomic Diversity of Shrews in Northeast Asia, Doklady Academiyi Nauk, 364, 3, 420-422 [In Russian].

Dokuchaev, N. E., 2004, First Registration of the Harvest Mouse (Micromys minutus Pallas) in Magadan Province, Russia, Russian Journal of Theriology, 3, 2, 59-61.

Dokuchaev, N. E., 2012, Shrews (Soricomorpha) and Rodents (Rodentia) Distribution Peculiarities on the Sea of Okhotsk Continental Coast, Vestnik NESC FEB RAS, 3, 118-123 [In Russian].

Dokuchaev, N. E., 2013, Structure of Shrews Communities (Sorex, Mammalia) in Southeastern Yakutia, Conference Dedicated to the Memory of Academician K. V. Simakov: Proceedings (Magadan, November 26-28, 2013), Magadan, NESC FEB RAS, 130-131 [In Russian].

Dokuchaev, N. E.; Dubinin, E. A.; Lazutkin, A. N.; Ivanov, V. V.; Grachev, A. I., 2011, Mammals, Flora and Fauna of the Magadansky Reserve, Magadan, NESC FEB RAS, 156-177, 283-285 [In Russian]. 
Dokuchaev, N. E.; Pospekhov, V. V., 2008, Shrews of the Shelikhov Bay Continental Coast (Sea of Okhotsk), Conservation of Biodiversity of Kamchatka and Coastal Waters: Materials of IX International Scientific Conference (Petropavlovsk-Kamchatsky, November 25-26, 2008), Petropavlovsk-Kamchatsky, Kamchatpress, 308310 [In Russian].

Egorov, O. V.; Naumov, S. P., 1965, The Animal World, Yakutia, Moscow, Nauka, 293-328 [In Russian].

Egorov, N. G.; Revin, Yu. V., 1992, Fauna Composition and Biotopic Distribution of Shrews (Sorex) in Southeastern Yakutia, $1^{\text {st }}$ All-Union Meeting on Biology of Insectivorous Mammals (4-7 February, 1992, Novosibirsk), Moscow, 52-54 [In Russian].

Gromov, I. M.; Yerbayeva, M. A., 1995, Mammals of Russia and Adjacent Territories. Lagomorphs and Rodents, St. Petersburg, ZIN RAS, 1995, 167 [In Russian].

Kishchinsky, A. A., 1972, New Data on the Distribution and Biology of Mammals from the Kolyma Highlands, Theriology, Novosibirsk, Nauka, 1, 192-205 [In Russian].

Krivosheyev, V. G., 1973, Modern Landscapes and Distribution of Mammals in Northeast Asia, Biological Problems of the North, 2, Magadan, IBPN DVNC AN USSR, 24-35 [In Russian].

Krivosheyev, V. G., 1988, Problems of Theriogeography of Northeast Asia, General and Regional Theriogeography, Moscow, Nauka, 33-74 [In Russian].

Mammals of Yakutia, 1971, Moscow, Nauka [In Russian].

Mordosov, I. I., 1997, Mammals of Western Yakutia (Fauna, Ecology, Problems of Preservation and Rational
Use), Diss. ... Sci. Report ... Doctor of Biology, Yakutsk [In Russian].

Mordosov, I. I., 2010, Mammal Fauna of the LenaAmga Interfluve, Vestnik of North-Eastern Federal University, 7, 2, 9-19 [In Russian].

Pavlinov, I. Ya.; Kruskop, S. V.; Varshavskiy, A. A.; Borisenko, A. V., 2002, Terrestrial Mammals of Russia, Identification Manual, Moscow, KMK Scientific Press [In Russian].

Popov, M. V., 1975, Small Mammals Fauna in the Eastern Part of the Lena-Vilyui Interfluve (Kenkeme River Valley), Ecology of Small Mammals in Yakutia, Yakutsk, 57-117 [In Russian].

Popov, M. V., 1977, Identification Guide on Mammals of Yakutia, Novosibirsk, Nauka [In Russian].

Revin, Yu. V., 1989, Mammals of Southern Yakutia, Novosibirsk, Nauka [In Russian].

Revin, Yu. V., 2003, Sorex minutus, Red Book of Sakha Republic (Yakutia), Yakutsk, Sakhapoligrafizdat, 2, 146147 [In Russian].

Tiunov, M. P., 2003b, Fauna and Distribution of Insectivorous Animals and Rodents in the Northwestern Coastal Region of the Sea of Okhotsk, Zoologichesky Zhurnal, 82, 6, 708-713 [In Russian].

Tiunov, M. P., 2003a, New Data on Distribution of Small Mammals in the Sea of Okhotsk Region and Adjacent Territories, Ibid., 82, 1, 123-125 [In Russian].

Volpert, Ya. L.; Shadrina E. G., 2002, Small Mammals of Siberia's North-East, Novosibirsk, Nauka [In Russian].

Yudin, B. S., 1989, Insectivorous Mammals of Siberia, Novosibirsk, Nauka [In Russian]. 